\title{
Hydroxyapatite nanoparticles inhibit the growth of human glioma cells in vitro and in vivo
}

\author{
This article was published in the following Dove Press journal: \\ International Journal of Nanomedicine \\ II July 2012 \\ Number of times this article has been viewed
}

\section{Sheng-Hua Chu' \\ Dong-Fu Feng' \\ Yan-Bin $\mathrm{Ma}^{\prime}$ \\ Zhi-Qiang $\mathrm{Li}^{2}$}

'Department of Neurosurgery, No 3 People's Hospital Affiliated to Shanghai Jiao Tong University School of Medicine, Shanghai, China;

${ }^{2}$ Department of Neurosurgery,

Zhongnan Hospital of Wuhan

University, Wuhan, China
Correspondence: Sheng-Hua Chu

Department of Neurosurgery, No 3 People's Hospital Affiliated to Shanghai Jiao Tong University School of Medicine, 280 Mohe Road, Bao Shan District, Shanghai 201900, China Tel +86 02I 5669 II0I ext 6I4I

Fax +8602156691662

Email shenghuachu@I26.com

\begin{abstract}
Hydroxyapatite nanoparticles (nano-HAPs) have been reported to exhibit antitumor effects on various human cancers, but the effects of nano-HAPs on human glioma cells remain unclear. The aim of this study was to explore the inhibitory effect of nano-HAPs on the growth of human glioma U251 and SHG44 cells in vitro and in vivo. Nano-HAPs could inhibit the growth of U251 and SHG44 cells in a dose- and time-dependent manner, according to methyl thiazoletetrazolium assay and flow cytometry. Treated with $120 \mathrm{mg} / \mathrm{L}$ and $240 \mathrm{mg} / \mathrm{L}$ nano-HAPs for 48 hours, typical apoptotic morphological changes were noted under Hoechst staining and transmission electron microscopy. The tumor growth of cells was inhibited after the injection in vivo, and the related side effects significantly decreased in the nano-HAP-and-drug combination group. Because of the function of nano-HAPs, the expression of c-Met, SATB1, $\mathrm{Ki}-67$, and bcl-2 protein decreased, and the expression of SLC22A18 and caspase-3 protein decreased noticeably. The findings indicate that nano-HAPs have an evident inhibitory action and induce apoptosis of human glioma cells in vitro and in vivo. In a drug combination, they can significantly reduce the adverse reaction related to the chemotherapeutic drug 1,3-bis(2chloroethyl)-1-nitrosourea (BCNU).
\end{abstract}

Keywords: glioma, hydroxyapatite nanoparticles, growth mechanism

\section{Introduction}

Glioma is the most common, and the primary, malignant brain tumor of the central nervous system. In recent years, great progress has been made in diagnosing and treating glioma, but its recurrence after resection still makes long-term prognosis unsatisfactory. ${ }^{1-3}$ Looking for new treatments and further studying its mechanism remain very important. With the development of nanotechnology, a new inorganic material, 1 nanoparticles (nano-HAPs), was found capable of inhibiting the proliferation of tumor cells. ${ }^{4,5}$ However, there is yet no report about the inhibitory effect of nano-HAPs on human glioma growth. In the current study, we sought to investigate the effect of nano-HAPs on the growth of human glioma U251 and SHG44 cells in vitro and in vivo and the mechanism involved, to provide a theoretical basis for clinical use.

\section{Materials and methods} Cell culture

Human glioma U251 (human glioma cells, from Wuhan University of China, Wuhan, China) and SHG44 cells (human glioma cells, from Fourth Military Medical University of China, Xi'an, China) were cultured in RPMI-1640 (Gibco Life 
Technologies, Paisley, Scotland, UK) supplemented with $10 \%$ fetal bovine serum, $100 \mu \mathrm{g} / \mathrm{mL}$ penicillin, and $100 \mu \mathrm{g} /$ $\mathrm{mL}$ streptomycin.

\section{Measurement of cell growth}

Cell proliferation was measured using the methyl thiazoletetrazolium (MTT) assay. ${ }^{6,7}$ Cells were seeded in plates at a density of $1 \times 10^{4}$ cells/well. When U251 and SHG44 cells were anchored to 96 -well plates, the culture medium containing various nano-HAPs (East China University of Science and Technology Institute of Biomaterials, Shanghai, China) concentrations $(0,15,30$, 60,120 , and $240 \mathrm{mg} / \mathrm{L}$ ) replaced the RPMI-1640 culture medium, the cells were incubated for another 24,48 , or 72 hours, and then $200 \mu \mathrm{L} 5 \mathrm{mg} / \mu \mathrm{L}$ MTT (Sigma, St Louis, MO) in phosphate-buffered saline (PBS) was added to each well and incubated for 4 hours; the precipitate was solubilized in $100 \mu \mathrm{L} 100 \%$ dimethylsulfoxide (Sigma) and shaken for 15 minutes. Absorbance values were determined using an enzyme-linked immunosorbent assay reader (Model 318; Shanghai Sunke Instruments Ltd., Shanghai, China) at $540 \mathrm{~nm}$. Each assay was performed nine times.

\section{Hoechst staining}

Typical apoptotic morphological changes were observed under Hoechst staining. ${ }^{8}$ Cells treated with $0 \mathrm{mg} / \mathrm{L}, 120 \mathrm{mg} / \mathrm{L}$, and $240 \mathrm{mg} / \mathrm{L}$ of nano-HAPs were harvested for 48 hours, fixed in $4 \%(\mathrm{v} / \mathrm{v})$ paraformaldehyde for 10 minutes, and then incubated for 10 minutes with Hoechst 33342 dye (Sigma) $(10 \mu \mathrm{g} / \mathrm{mL})$. U251 and SHG44 cells were observed under an inverted fluorescence microscope (IX70; Olympus, Tokyo, Japan) after being washed with PBS.

\section{Transmission electron-microscopic assay}

Typical apoptotic morphological changes were also observed by transmission electron-microscopic assay. ${ }^{9}$ Cells were seeded in flasks. When U251 and SHG44 cells were anchored to plates, the different concentrations $(0,120$, and $240 \mathrm{mg} / \mathrm{L})$ of nano-HAPs were added, and the U251 and SHG44 cells were incubated for 48 hours; the specimens were postfixed in $1 \%$ osmium tetroxide $/ 0.1 \mathrm{M}$ sodium cacodylate buffer, dehydrated in a graded series of ethanol, and embedded after rinsing three times. ${ }^{10}$ The ultrathin sections of the specimens were stained with lead citrate and uranyl acetate, and observed with a transmission electron microscope. Each assay was performed in triplicate.

\section{Measurement of apoptosis by flow cytometry}

The suspended single cells of U251 and SHG44, treated 48 hours with nano-HAPs at various concentrations ( 0 , 120 , and $240 \mathrm{mg} / \mathrm{L}$ ), were harvested. After washing with PBS fixed in $70 \%$ cold ethanol treated with $10 \mathrm{~g} / \mathrm{L}$ RNasere suspended and stained with $10 \mathrm{~g} / \mathrm{L}$ propidium iodine. U251 and SHG44 cells were stained directly with PI at a concentration of $10 \mu \mathrm{g} / \mathrm{mL}$ and $2 \%$ Annexin-V-Fluos (Roche, Basel, Switzerland) in incubation buffer for 10 minutes. U251 and SHG44 cells were acquired with the FACS calibrator (BD) after setting the instrument with the controls (nontreated, stained cells), after two washes in PBS. In this experiment, U251 and SHG44 cells with early apoptotic signals, stained with annexin- $V$, and cells with late death signals, stained with PI, were considered and quantified, and the apoptotic cells were analyzed using CellQuest software. ${ }^{11,12}$ Each assay was performed in triplicate.

\section{Murine xenograft model}

Male, 4-to-6-week-old BALB/c athymic nude mice were subcutaneously injected with $2 \times 10^{6}$ human glioma cells. The 60 human glioma-bearing nude mice were randomly divided into five groups. Drug injection was through the tail vein every other day for 3 weeks. Group A (control group) was injected with $2 \mathrm{~mL}$ normal saline each time; Group B was injected with a nano-HAP solution of $25 \mathrm{mg} / \mathrm{kg}$; Group C was injected with a nano-HAP solution of $50 \mathrm{mg} / \mathrm{kg}$; Group D was injected with the chemotherapy drug 1,3-bis(2-chloroethyl)1-nitrosourea (BCNU) at $25 \mathrm{mg} / \mathrm{kg}$; and Group E was injected with a mixture of nano-HAP solution $(25 \mathrm{mg} / \mathrm{mL})$ and BCNU ( $25 \mathrm{mg} / \mathrm{mL}$ ). The doses were both $25 \mathrm{mg} / \mathrm{kg}$. Tumor diameters were measured at regular intervals with digital calipers, and the tumor volume in cubic millimeters was calculated by this formula: volume $=(\text { width })^{2} \times$ length $/ 2$. The animal experiments in this study were performed in compliance with the guidelines of the Institute for Medical School Institutes at Shanghai Jiao Tong University and Wuhan University.

\section{Monitoring the growth state of human glioma-bearing nude mice}

The human glioma-bearing nude mice were housed in a standard animal laboratory; the general growth-state changes of the animals, such as water-drinking, food intake, color pattern, nasal and oral discharge, and activity, were followed up every day. The human glioma-bearing nude mice were weighed, before feeding, every 3 days in the early morning. ${ }^{13}$ 


\section{Transferase-mediated dUTP nick end labeling staining}

Sections of glioma tissues of nude mice were deparaffinized in xylene, rehydrated, washed with PBS, and treated with $20 \mu \mathrm{g} / \mathrm{mL}$ of Proteinase $\mathrm{K}$ (Roche) for $10 \mathrm{~min}$ utes at room temperature. ${ }^{14}$ Terminal deoxynucleotidyl transferase-mediated dUTP nick end labeling reactions were conducted using Apoptag (Chemicon) according to the manufacturer's instructions, and detected using $\mathrm{Cy} 3-$ anti-digoxygenin (Jackson). Microscopy was done on a Nikon E-600 microscope equipped with a QICam Fast 1394 camera (Q Imaging) and IVision imaging software (BioVision Technologies).

\section{Western blotting analysis}

The suspended single U251 and SHG44 cell treatment with nano-HAPs at various concentrations $(0,120$, and $240 \mathrm{mg} / \mathrm{L}$ ) for 48 hours were harvested. U251 and SHG44 cells were washed in PBS and lysed in buffer using the standard methods. ${ }^{15,16}$ The samples of glioma tissues of nude mice in the five groups were homogenized in an RIPA lysis buffer. Lysates were cleared by centrifugation $(14,000 \mathrm{rpm})$ at $4^{\circ} \mathrm{C}$ for 30 minutes. Protein samples (approximately $40 \mu \mathrm{g}$ ) were separated by SDS-PAGE (15\% gel), transferred to a PVDF membrane, and nonspecific binding sites blocked by incubation in 5\% nonfat milk for 60 minutes. Membranes were incubated at $4^{\circ} \mathrm{C}$ overnight with anti-c-Met antibody (1:400 dilution), anti-SLC22A18 antibody (1:1000 dilution), anti-SATB1 antibody (1:200 dilution), anti-caspase-3 antibody (1:500 dilution), antibcl-2 antibody (1:300 dilution), or anti-Ki-67 antibody (1:100 dilution). Then the membranes were washed three times with TBST for 10 minutes and probed with the HRPconjugated secondary antibody (at 1:2000 dilution) at room temperature for 30 minutes. The membrane was developed by an enhanced chemiluminescence system (ECL, Pierce) after being washed three times.

\section{Statistical analysis}

Statistical analyses were done and graphs created using the Statistical Package for the Social Sciences (version 12.0 for Windows; SPSS, Chicago, IL). Quantitative values were expressed as means \pm standard deviation. Statistical differences between groups were examined using the Fisher's exact test. $P$-values less than 0.05 were considered statistically significant.

\section{Results \\ Effect of nano-HAPs on the growth of cells}

MTT assays demonstrated that cell viability was reduced after 24-hour incubation, and the viability of U251 and SHG44 cells decreased when the concentration and time period increased. There were significant differences in the viability of the U251 and SHG44 cells incubated with the various concentrations $(0,15,30,60,120$, and $240 \mathrm{mg} / \mathrm{L})$ of nano-HAPs, and the viability of cells was also significantly inhibited by nano-HAPs as time increased. When cells were exposed to $240 \mathrm{mg} / \mathrm{L}$ HAP for 72 hours, the U251 and SHG44 cells' viability decreased greatly (to $31.73 \% \pm 2.03 \%$ and $32.28 \% \pm 2.12 \%$, respectively, compared with the control group's viability). ANOVA analysis and Dunnett's test revealed that nano-HAPs inhibited the U251 and SHG44 cells' growth in a dose- and time-dependent manner (Figure 1).

\section{Effect of nano-HAPs on the morphology of cells}

The nucleus in the control group was round and big, with a smooth nuclear membrane, free of condensation and fragmentation (Figure 2). But typical apoptotic morphological changes were found in the U251 and SHG44 cells 48 hours after treatment with 120 and $240 \mathrm{mg} / \mathrm{L}$ nano-HAPs. The higher the concentration of nano-HAPs, the more apoptotic cells there were. The changes included detachment, deformation, and shrinkage from the culture dishes. Chromatin margination and nuclear condensation were obvious from Hoechst staining (Figure 2A), and segmentation, nuclear

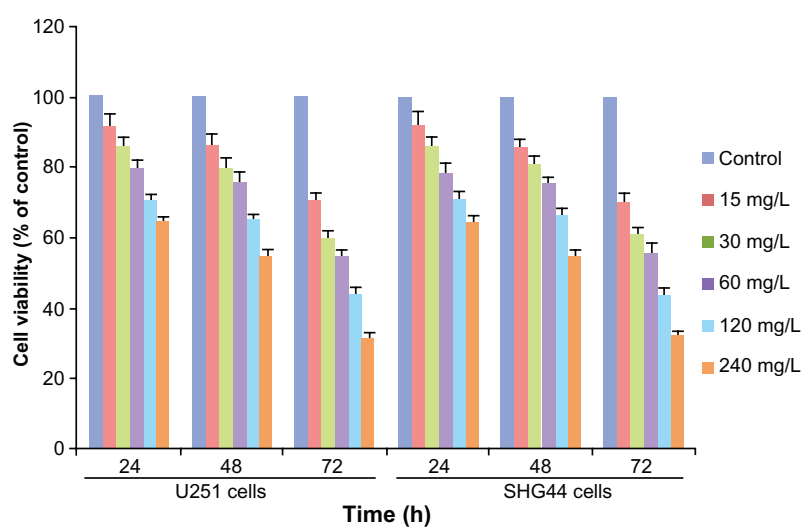

Figure I Effects of HAP nanoparticles on the viability of U25I and SHG44 cells determined by MTT assay.

Abbreviations: HAP, hydroxyapatite; MTT, methyl thiazoletetrazolium; SHG44, human glioma SHG44 cells; U25I, human glioma U25I cells. 
A
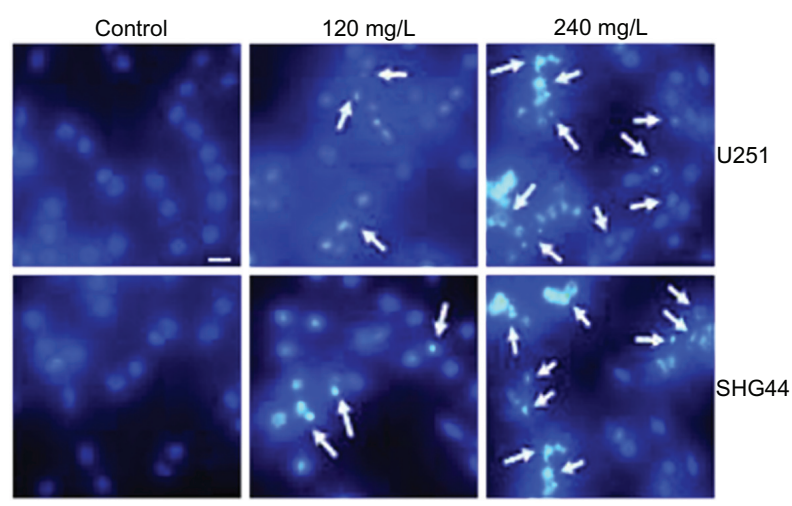

B

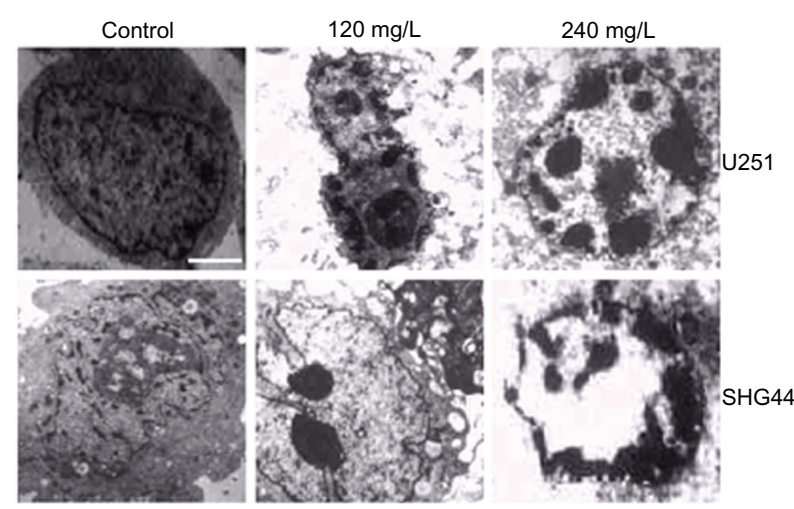

Figure 2 Effect of HAP nanoparticles on the morphologic changes of cells. (A) Hoechst 33342 staining. The apoptotic cells were marked by green fluorescence; scale bar, $20 \mu \mathrm{m}$. (B) Transmission electron microscopy.

Notes: Original magnification $\times 6000$; scale bar, I $\mu \mathrm{m}$.

Abbreviations: HAP, hydroxyapatite; SHG44, human glioma SHG44 cells; U25I, human glioma U25I cell.

condensation, and chromatin margination were observed by transmission electron microscopy (Figure 2B).

\section{Effect of nano-HAPs on the apoptosis of cells in vitro}

To quantitate nano-HAP-induced apoptotic cell death in U251 and SHG44 cells, approximately $1 \times 10^{6} \mathrm{U} 251$ and SHG44 cells were double stained with Annexin-V-FITC and propidium iodide (PI) at different times, post-transfection. Apoptotic cell death was detected 48 hours after treatment with 120 and $240 \mathrm{mg} / \mathrm{L}$ nano-HAPs (Figure 3A). FACS analysis identified significantly higher numbers of apoptotic cells in nano-HAPtreated groups than in the control group (Figure 3B).

\section{Effect of nano-HAPs on the expression of c-Met, SLC22A I 8, and SATBI protein in U25I and SHG44 cells}

Total protein was extracted from the U251 and SHG44 cells and analyzed by western blotting. The c-Met protein inhibition rates of $240 \mathrm{mg} / \mathrm{L}$ nano-HAPs in glioma U251 and SHG44 cells were, respectively, $82.65 \%$ and $76.04 \%$, compared with the control group (Figure 4). Each treatment
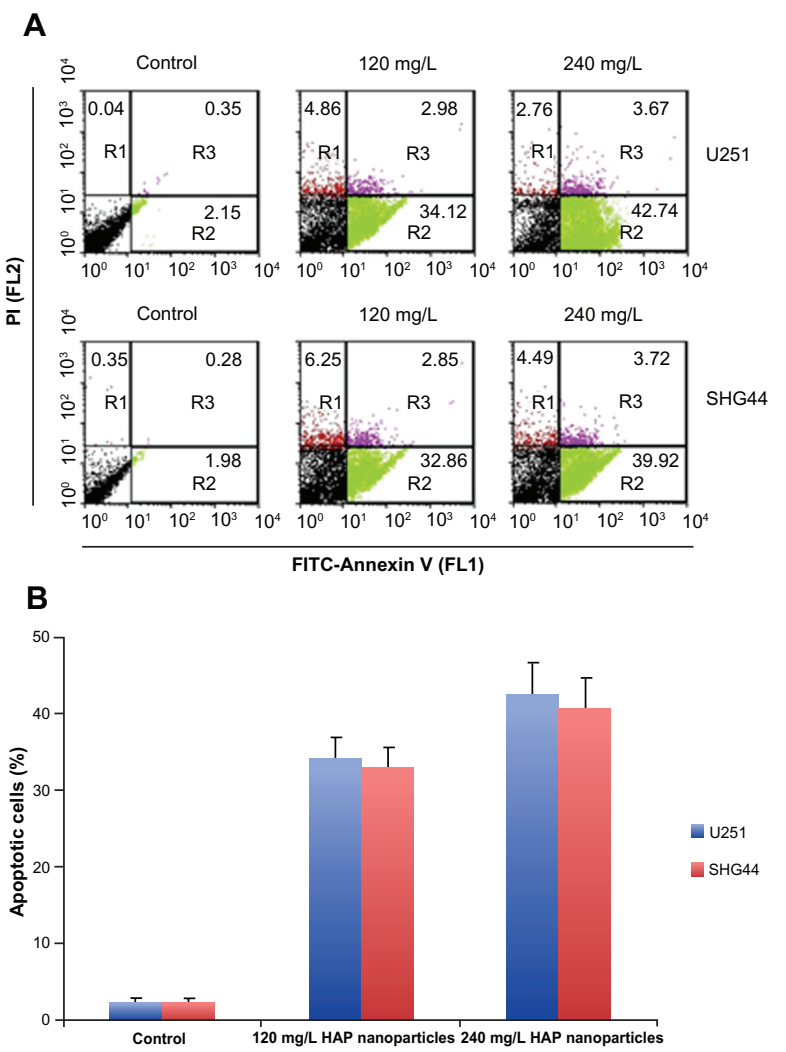

Figure 3 FACS analysis of Annexin- $V$ staining of cells after treatment with 120 and $240 \mathrm{mg} / \mathrm{L}$ HAP nanoparticles. (A) Representative FACS scatter plots of cells. (B) Percentages of apoptotic cells in cells after treatment.

Abbreviations: HAP, hydroxyapatite; PI, propidium iodide; SHG44, human glioma SHG44 cells; U25I, human glioma U25I cells.

group revealed that the expression of SLC22A18 increased, whereas the expression of SATB1 and Ki-67 decreased in glioma U251 and SHG44 cells (Figure 4).

\section{Change of the growth state of human glioma-bearing nude mice}

Before drug injection in each group, the weights between all the groups had no significant differences, the general state of health of the nude mice was very good, and activity and food intake were normal. The nude mice in the control group started to have symptoms of gradual failure two weeks after injection, the mice's food intake and activity worsened, their nasal and oral discharge increased, and their stools became loose. Their weight in the two nano-HAP-treated groups was higher than in the control group (Figure 5), and the time it took the two nano-HAP-treated groups to have symptoms of gradual failure was also longer than in the control group. At 1 week after injection, the weight of the nude mice was lower than that in the control group, and at 3 weeks after injection, the weight of the nude mice was lower than other groups. The activity and food intake of the nude mice decreased significantly after three drug injections. After these injec- 

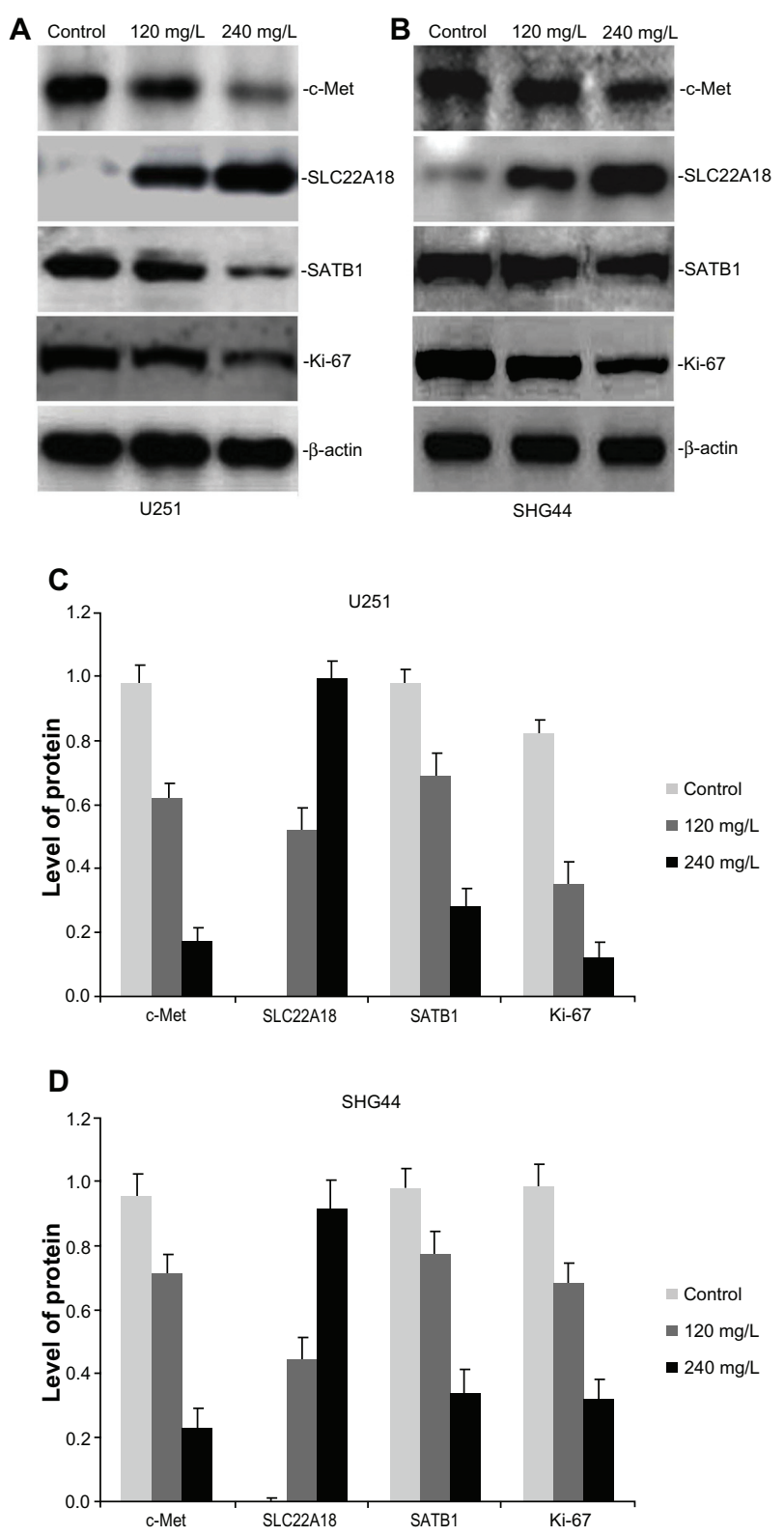

Figure 4 Effect of HAP nanoparticles on the expression of c-Met, SLC22AI8 and SATBI protein in $\mathrm{U} 25 \mathrm{I}$ and SHG44 cells in vitro. (A and B) Representative images of western blotting analysis of c-Met, SLC22AI 8 and SATBI expression in in U25I and SHG44 cells. (C and D) Level of the c-Met, SLC22AI 8 and SATBI protein expression in $\mathrm{U} 25 \mathrm{I}$ and SHG44 cells.

Abbreviations: HAP, hydroxyapatite; U25I, human glioma U25I cells; SHG44, human glioma SHG44 cells.

tions, the weight of the drug-combination group decreased, but there was no significant difference compared with the group receiving the chemotherapy drug BCNU.

\section{Effects of the nano-HAPs on tumor growth in vivo}

As shown in Figure 6, the control group's U251 and SHG44 xenograft tumors formed and grew very rapidly. However, xenograft tumor formation treated with both nanoHAPs and BCNU was significantly delayed. At the end of
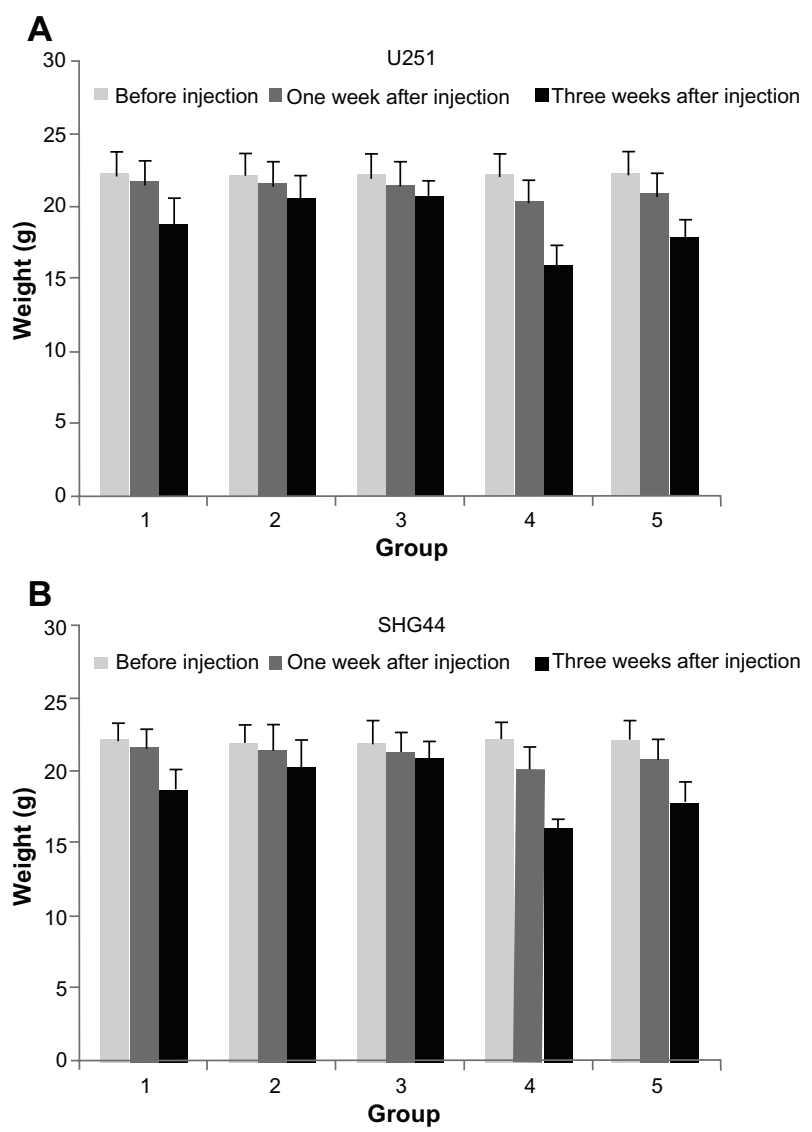

Figure 5 Effects of HAP nanoparticles on weight of tumor-bearing nude mice. Notes: Lane I, the control group; lane 2, nano-HAP solution ( $25 \mathrm{mg} / \mathrm{kg}$ ) group; lane 3 , nano-HAP solution ( $50 \mathrm{mg} / \mathrm{kg}$ ) group); lane 4, BCNU (25 mg/kg) group; lane 5, nanoHAP solution $(25 \mathrm{mg} / \mathrm{mL})$ and $\mathrm{BCNU}(25 \mathrm{mg} / \mathrm{mL})$ group.

Abbreviations: Nano-HAPs, hydroxyapatite nanoparticles; BCNU, 1,3-bis(2chloroethyl)-I-nitrosourea; SHG44, human glioma SHG44 cells; U25I, human glioma U25I cells.

the experiment, the U251- and SHG44-cell tumors treated with both nano-HAPs and BCNU were significantly smaller than the tumors from the other groups.

\section{Transferase-mediated dUTP nick end labeling assay}

As shown in Figure 7, visualized using the DAB substrate, the brown color indicates apoptotic nuclei. Apoptosis was calculated as percentage of at least 1000 cells. After 28 days, the mixed nano-HAP and BCNU treatment of glioma U251 and SHG44 cells resulted in significantly higher apoptotic indexes (68.5\% and $67.7 \%$, respectively), compared to those of the other groups.

\section{Caspase- 3 and bcl-2 protein expression in tumor tissues}

Total protein was exacted from tumor tissues from the five groups and analyzed by western blotting. Each treatment group revealed that the expression of caspase-3 increased in 
A
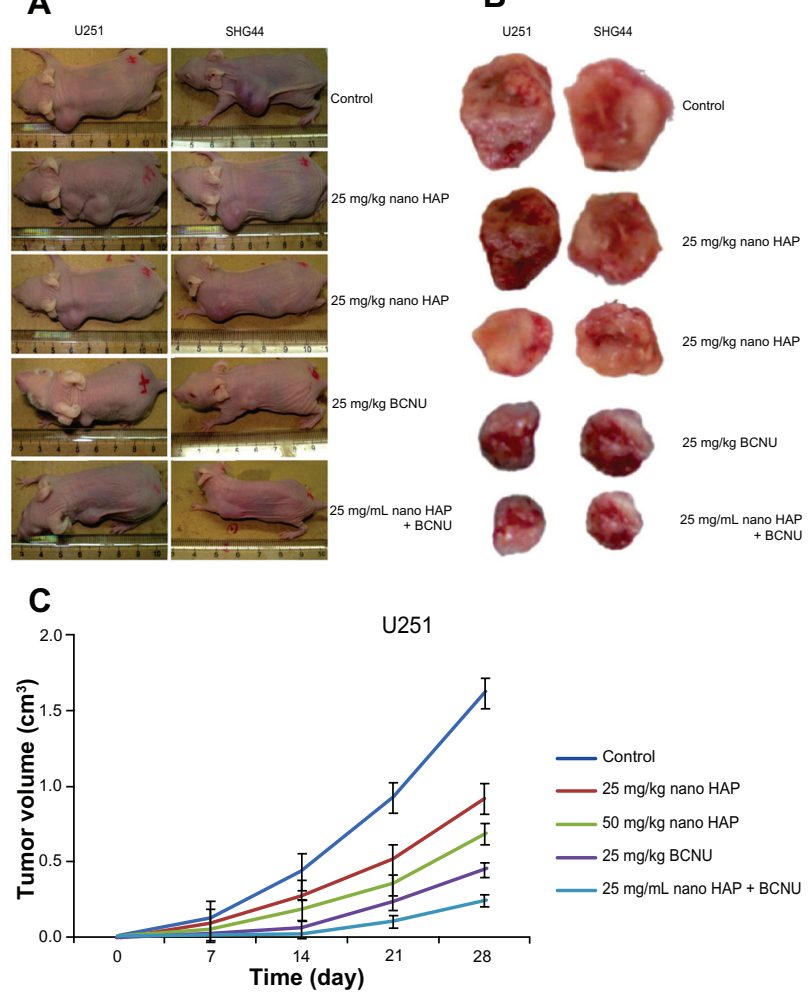

D

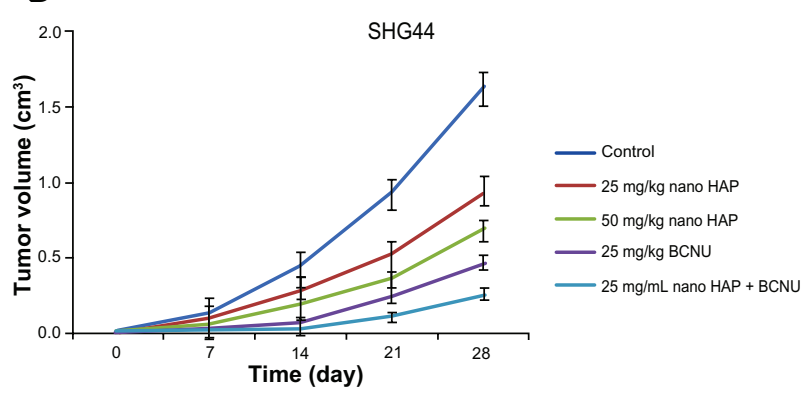

Figure 6 Effect of HAP nanoparticles on tumor growth in vivo. (A and B) Subcutaneous tumor model. (C and D) Tumor growth curves of each group over 28 days. Abbreviation: Nano-HAPs, hydroxyapatite nanoparticles; BCNU, I,3-bis(2chloroethyl)-I-nitrosourea; U25I, human glioma U25I cells; SHG44, human glioma SHG44 cells.

the glioma U251 and SHG44 cells of nude mice (Figure 8). The bcl-2 protein inhibition rates for nano-HAP plus $\mathrm{BCNU}$, as compared with the control group, were $81.63 \%$ in the glioma U251 cells and $85.11 \%$ in the SHG44 cells (Figure 8).

\section{Discussion}

Hydroxyapatite has been widely used as a new biomaterial for oral cavity medicine and bone damage, is used as a medicine carrier in the body, and has good tissue compatibility both outside and inside the body. ${ }^{17-19}$ Nano-HAP has little excitatory effect on blood vessels: nano-HAP medicine could be delivered by intravenous injection..$^{20,21}$ In this study,
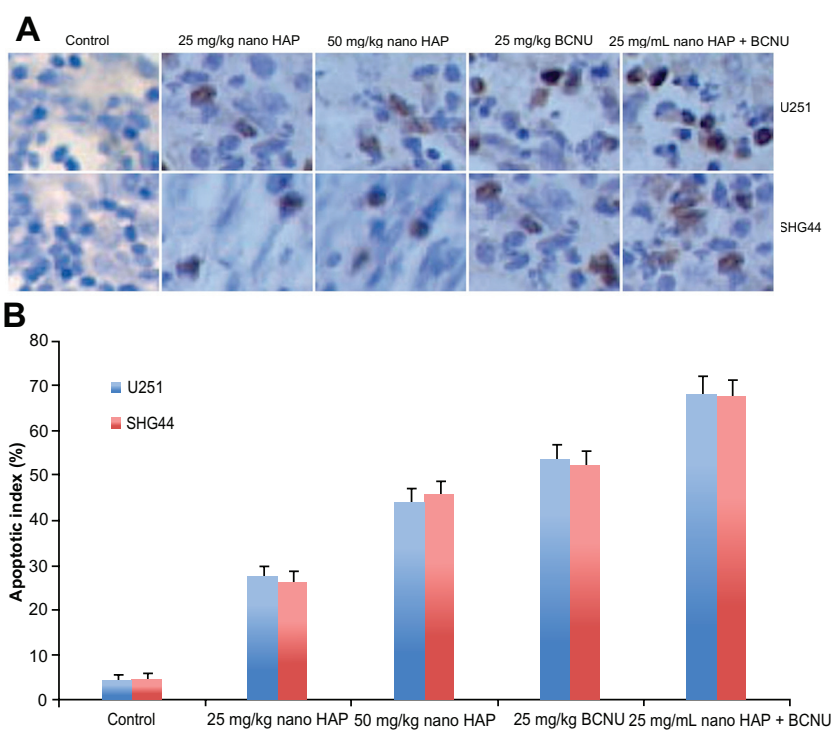

Figure 7 In vivo assessment of apoptosis by TUNEL assay in the glioma tissues of nude mice at one month after treatment. (A) Representative images of TUNEL assay. Original magnification: $\times 400$. (B) Apoptotic index in the glioma U25I and SHG44 cell tissues of nude mice.

Abbreviations: TUNEL, transferase-mediated dUTP nick end labeling; U25I, human glioma U25I cells.

nano-HAPs were synthesized by the sol-coagel method, which had a good dispersive effect, and the very uniform size of nano-HAPS was about $50 \mathrm{~nm}$, which had the advantages of providing high surface energy and so on. Hydroxyapatite nanoparticles were found capable of inhibiting the proliferation of tumor cells. ${ }^{4,5}$

In this study, it was found that different concentrations of nano-HAPs significantly inhibited the proliferation of human glioma U251 and SHG44 cells in a dose- and time-dependent manner, as observed using MTT assays. Typical apoptotic morphological changes such as nuclear chromatin fragmentation and condensation, cytoplasmic budding, cell shrinkage, and apoptotic body formation were observed after U251 and SHG44 cells were treated for 48 hours with HAP nanoparticles, as observed using Hoechst staining and transmission electron microscopy. Quantified by flow cytometry, the higher the concentration of HAP nanoparticles, the more apoptotic cells there were. Moreover, this study has shown that nano-HAPS had a significantly inhibitory effect on the growth of the human glioma U251 and SHG44 cells in nude mice, and induced apoptosis after its intravenous injection into same. The chemotherapy drug BCNU's inhibition of human glioma growth was greater than that of nano-HAP alone; however, adverse reaction to $\mathrm{BCNU}$ was also evident: the activity and food-intake of nude mice were evidently reduced after being continuously injected with BCNU. And their body weights were significantly lower than those 

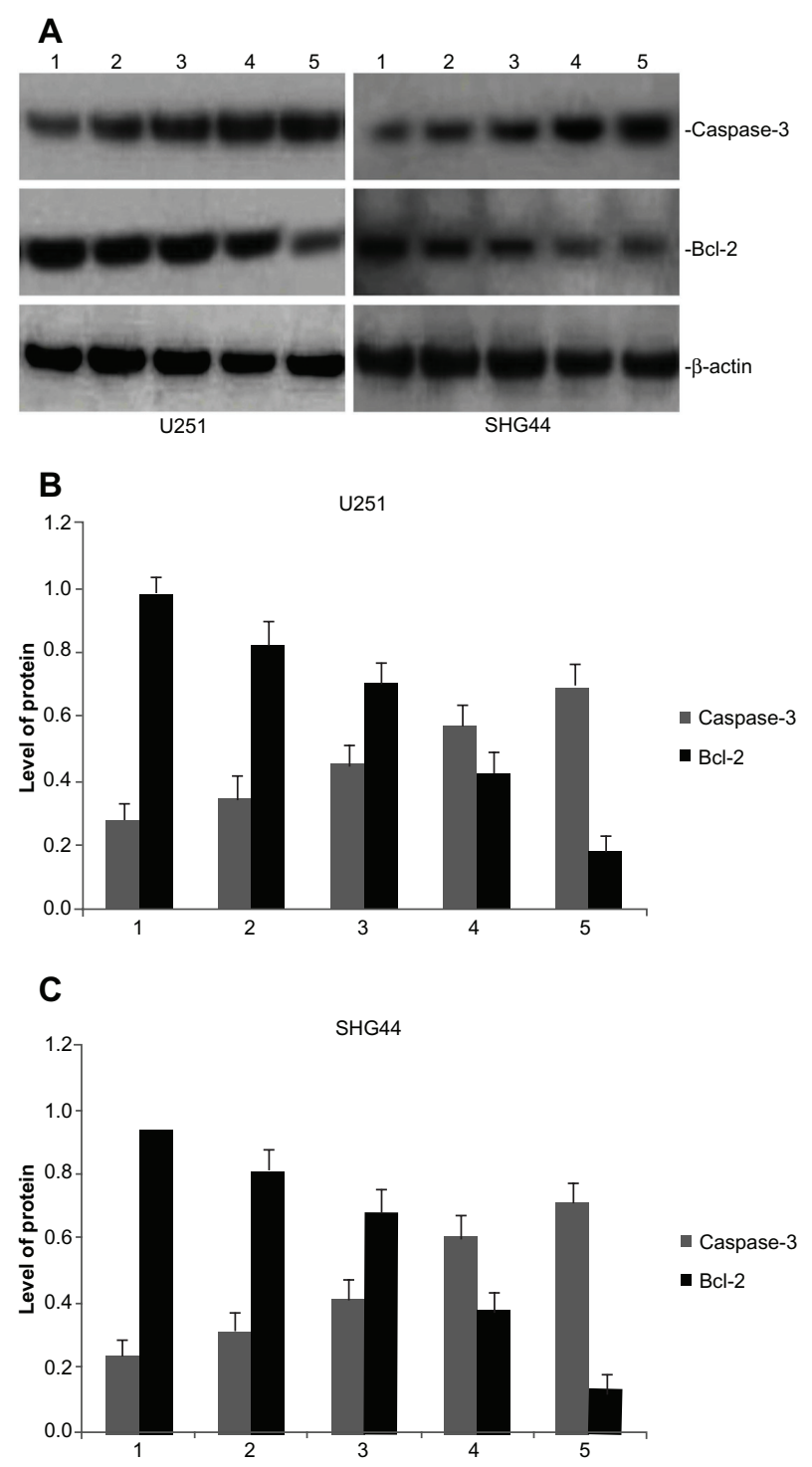

Figure 8 Effect of HAP nanoparticles on the expression of caspase-3 and bcl-2 protein in U25I and SHG44 cells in vivo. (A) Representative images of western blotting analysis of caspase- 3 and bcl-2 expression. (B and $\mathbf{C}$ ) Level of the caspase-3 and bcl-2 protein expression in tumors.

Notes: Lane I, the control group; lane 2, nano-HAP solution $(25 \mathrm{mg} / \mathrm{kg})$ group; lane 3 , nano-HAP solution $(50 \mathrm{mg} / \mathrm{kg}$ ) group; lane 4, BCNU (25 mg/kg) group; lane 5, nanoHAP solution $(25 \mathrm{mg} / \mathrm{mL})$ and $B C N U(25 \mathrm{mg} / \mathrm{mL})$ group.

Abbreviations: Nano-HAP, hydroxyapatite nanoparticles; U25I, human glioma U25 I cells; SHG44, human glioma SHG44 cells; BCNU, I,3-bis(2-chloroethyl)-I-nitrosourea.

in the other groups. These findings showed no evidence of adverse bodily reactions caused by nano-HAPs. Therefore, the present research indicates that nano-HAPs can inhibit the growth of human glioma cells and induce apoptosis, in vitro and in vivo.

In this study, it was also shown that not only do nano-HAPs have an antitumor effect, but they also cooperate strongly with other antitumor drugs. In the drug combination group, the inhibition rates of human glioma U251 and SHG44 cells were the highest in the in vivo experiments. And the general state of the mice in the two groups was quite different after their being injected with the same dosage of BCNU. Dynamic monitoring of body weight showed that the effect of BCNU on the physiological function of the mice in the drug combination group was evidently less than in BCNU-only group. The mice's general state in the former group was also obviously better than it was in the latter group. Combined with nano-HAPs (whose high surface energy and large surface area make them ideal drug carriers), BCNU could play an important role in tumor treatment.

We have previously found that HGF and its receptor, c-Met, played an important role in the formation, progression, and angiogenesis of glioma, that they could promote tumor proliferation and intratumoral microvascular formation, and that they were closely related to the prognosis of the patients. ${ }^{3}$ Antisense oligodeoxynucleotide targeting of the c-Met gene or c-Met-targeted RNA interference downregulated or inhibited c-Met expression, which inhibited U251 glioma cells growth and metastasis, induced cell apoptosis, and increased the sensitivity of human glioma cells to paclitaxel. ${ }^{22-25}$ Recently, we have found that SLC22A18 downregulation via promoter methylation was associated with the development and progression of glioma, that it represented a candidate biomarker, and that the elevated expression of SLC22A18 increased the sensitivity of U251 glioma cells to BCNU., ${ }^{1,26}$

In recent years, SATB1 has attracted considerable attention because of its high expression in tumor tissues as a variety of malignancies, which suggests its important role in promoting tumor growth, invasion, and metastasis; it may also have potential value as a candidate for cancer therapy. ${ }^{27-29}$ Our results showed that the expression of c-Met, SATB1, and Ki-67 protein decreased and that SLC22A18 protein in glioma U251 and SHG44 cells increased after the cells were treated with various concentrations of hydroxyapatite nanoparticles in vitro. Owing to the function of nano-HAPs, the caspase- 3 protein in tumor tissue increased, and the expression of bcl-2 protein clearly decreased. This might be the first report about the antitumor mechanism of nano-HAPs decreasing the expression of c-Met, SATB1, Ki-67, and bcl-2 protein while increasing the expression of SLC22A18 and caspase- 3 protein. This could provide a basis for its clinical application.

\section{Conclusion}

In this study we have shown that not only do hydroxyapatite nanoparticles have an obvious antineoplastic function in vitro and in vivo, but also that they reduce the poisonous, adverse reactions to $\mathrm{BCNU}$, strongly cooperate with certain other chemotherapy drugs, decrease the toxicity of certain 
other chemotherapy drugs, and might become a new clinical antineoplastic drug. They might work by reducing the expression of c-Met, SATB1, Ki-67, and bcl-2 and by increasing the expression of SLC22A18 and caspase-3.

\section{Acknowledgments}

The authors would like to thank East China University of Science and Technology Institute of Biomaterials for providing the hydroxyapatite nanoparticles. This work was supported by grants from the Innovation Program of Shanghai Municipal Education Commission (12YZ046) and the Natural Science Foundation of China (30901535).

\section{Disclosure}

The authors report no conflicts of interest in this work.

\section{References}

1. Chu SH, Feng DF, Ma YB, et al. Promoter methylation and downregulation of SLC22A18 are associated with the development and progression of human glioma. J Transl Med. 2011;9(1):156.

2. Chu SH, Ma YB, Feng DF, et al. Correlation of low SLC22A18 expression with poor prognosis in patients with glioma. J Clin Neurosci. 2012;19(1):95-98.

3. Chu SH, Yuan XH, Jiang PC, et al. The expression of hepatocyte growth factor and its receptor in brain astrocytomas. Zhonghua Yi Xue Za Zhi. 2005;85(12):835-838.

4. Motskin M, Müller KH, Genoud C, Monteith AG, Skepper JN. The sequestration of hydroxyapatite nanoparticles by human monocytemacrophages in a compartment that allows free diffusion with the extracellular environment. Biomaterials. 2011;32(35):9470-9482.

5. Chakraborty S, Das T, Sarma HD, Venkatesh M, Banerjee S. Preparation and preliminary studies on 177Lu-labeled hydroxyapatite particles for possible use in the therapy of liver cancer. Nucl Med Biol. 2008;35(5):589-597.

6. Chu SH, Zhu ZA, Yuan XH, Li ZQ, Jiang PC. In vitro and in vivo potentiating the cytotoxic effect of radiation on human U251 gliomas by the c-Met antisense oligodeoxynucleotides. J Neurooncol. 2006; 80(2):143-149.

7. Sheng-Hua C, Yan-Bin M, Zhi-An Z, et al. Radiation-enhanced hepatocyte growth factor secretion in malignant glioma cell lines. Surg Neurol. 2007;68(6):610-614.

8. Wang P, Zhen H, Jiang X, et al. Boron neutron capture therapy induces apoptosis of glioma cells through Bcl-2/Bax. BMC Cancer. 2010;10(12):661.

9. Liu ZS, Tang SL, Ai ZL. Effects of hydroxyapatite nanoparticles on proliferation and apoptosis of human hepatoma BEL-7402 cells. World J Gastroenterol. 2003;9(9):1968-1971.

10. Johkura K, Cui L, Asanuma K, Okouchi Y, Ogiwara N, Sasaki K. Cytochemical and ultrastructural characterization of growing colonies of human embryonic stem cells. J Anat. 2004;205(4):247-255.

11. Hassan MK, Watari H, Han Y, et al. Clusterin is a potential molecular predictor for ovarian cancer patient's survival: targeting clusterin improves response to paclitaxel. J Exp Clin Cancer Res. 2011;30(12):113.
12. Chu SH, Ma YB, Feng DF, Zhang H, Qiu JH, Zhu ZA. Effect of 5-Aza2'-deoxycytidine on SLC22A18 in glioma U251 cells. Mol Med Report. 2012;5(1):138-141.

13. Hu J, Liu ZS, Tang SL, He YM. Effect of hydroxyapatite nanoparticles on the growth and p53/c-Myc protein expression of implanted hepatic VX2 tumor in rabbits by intravenous injection. World J Gastroenterol. 2007;13(20):2798-2802.

14. Pierstorff E, Ho D. Nanomembrane-driven co-elution and integration of active chemotherapeutic and anti-inflammatory agents. Int $J$ Nanomedicine. 2008;3(4):425-433.

15. Chu SH, Feng DF, Ma YB, et al. Expression of HGF and VEGF in the cerebral tissue of adult rats with chronic hydrocephalus after subarachnoid hemorrhage. Mol Med Report. 2011;4(5):785-791.

16. Chu SH, Feng DF, Ma YB, Zhu ZA, Zhang H, Qiu JH. Stabilization of hepatocyte growth factor mRNA by hypoxia-inducible factor $1 . \mathrm{Mol}$ Biol Rep. 2009;36(7):1967-1975.

17. Fu Q, Hong Y, Liu X, Fan H, Zhang X. A hierarchically graded bioactive scaffold bonded to titanium substrates for attachment to bone. Biomaterials. 2011;32(30):7333-7346.

18. Singh MK, Gracio J, LeDuc P, et al. Integrated biomimetic carbon nanotube composites for in vivo systems. Nanoscale. 2010;2(12): 2855-2863.

19. Fernandez JM, Molinuevo MS, Cortizo MS, Cortizo AM. Development of an osteoconductive PCL-PDIPF-hydroxyapatite composite scaffold for bone tissue engineering. J Tissue Eng Regen Med. 2011;5(6):e126-e135.

20. Hou CJ, Liu JL, Li X, Bi LJ. Insulin promotes bone formation in augmented maxillary sinus in diabetic rabbits. Int J Oral Maxillofac Surg. 2012;41(3):400-407.

21. Sung MS, Kim HG, Woo KI, Kim YD. Ocular ischemia and ischemic oculomotor nerve palsy after vascular embolization of injectable calcium hydroxylapatite filler. Ophthal Plast Reconstr Surg. 2010;26(4):289-291.

22. Chu SH, Zhang H, Ma YB, et al. c-Met antisense oligodeoxynucleotides as a novel therapeutic agent for glioma: in vitro and in vivo studies of uptake, effects, and toxicity. J Surg Res. 2007;141(2):284-288.

23. Chu S, Yuan X, Li Z, Jiang P, Zhang J. C-Met antisense oligodeoxynucleotide inhibits growth of glioma cells. Surg Neurol. 2006;65(6):533-538.

24. Chu SH, Feng DF, Zhang H, et al. c-Met-targeted RNA interference inhibits growth and metastasis of glioma U251 cells in vitro. J Neurooncol. 2009;93(2):183-189.

25. Chu SH, Ma YB, Feng DF, Zhang H, Qiu JH, Zhu ZA. c-Met antisense oligodeoxynucleotides increase sensitivity of human glioma cells to paclitaxel. Oncol Rep. 2010;24(1):189-194.

26. Chu SH, Ma YB, Feng DF, Zhang H, Qiu JH, Zhu ZA. Elevated expression of solute carrier family 22 member 18 increases the sensitivity of U251 glioma cells to BCNU. Oncol Lett. 2011;2(6):1139-1142.

27. Agrelo R, Souabni A, Novatchkova M, et al. SATB1 defines the developmental context for gene silencing by Xist in lymphoma and embryonic cells. Dev Cell. 2009;16(4):507-516.

28. Cheng C, Lu X, Wang G, et al. Expression of SATB1 and heparanase in gastric cancer and its relationship to clinicopathologic features. APMIS. 2010;118(11):855-863.

29. Choi JY, Pratap J, Javed A, et al. Subnuclear targeting of Runx/Cbfa/AML factors is essential for tissue-specific differentiation during embryonic development. Proc Natl Acad Sci U S A. 2001;98(15):8650-8655.

\section{Publish your work in this journal}

The International Journal of Nanomedicine is an international, peerreviewed journal focusing on the application of nanotechnology in diagnostics, therapeutics, and drug delivery systems throughout the biomedical field. This journal is indexed on PubMed Central, MedLine, CAS, SciSearch $\AA$, Current Contents ${ }^{\circledR} /$ Clinical Medicine,

\section{Dovepress}

Journal Citation Reports/Science Edition, EMBase, Scopus and the Elsevier Bibliographic databases. The manuscript management system is completely online and includes a very quick and fair peer-review system, which is all easy to use. Visit http://www.dovepress.com/ testimonials.php to read real quotes from published authors. 